\title{
Review Article \\ Novel Vitamin D Analogs for Prostate Cancer Therapy
}

\author{
Tai C. Chen ${ }^{1}$ and Atsushi Kittaka ${ }^{2}$ \\ ${ }^{1}$ Boston University School of Medicine, Room M-1022, 715 Albany Street, Boston, MA 02118, USA \\ ${ }^{2}$ Faculty of Pharmaceutical Sciences, Teikyo University, Midori-ku, Sagamihara, Kanagawa 252-5195, Japan
}

Correspondence should be addressed to Tai C. Chen, taichen@bu.edu

Received 15 May 2011; Accepted 3 June 2011

Academic Editors: A. M. El-Assmy, T. Nelius, K. Pummer, and F. Staerman

Copyright ( 2011 T. C. Chen and A. Kittaka. This is an open access article distributed under the Creative Commons Attribution License, which permits unrestricted use, distribution, and reproduction in any medium, provided the original work is properly cited.

Prostate cells contain specific receptors for $1 \alpha, 25$-dihydroxyvitamin $\mathrm{D}\left[1 \alpha, 25(\mathrm{OH})_{2} \mathrm{D}\right]$ or calcitriol, the active form of vitamin D. $1 \alpha, 25(\mathrm{OH})_{2} \mathrm{D}$ is known to inhibit the proliferation and invasiveness of prostate cancer cells. These findings support the use of $1 \alpha, 25(\mathrm{OH})_{2} \mathrm{D}$ for prostate cancer therapy. However, $1 \alpha, 25(\mathrm{OH})_{2} \mathrm{D}$ can cause hypercalcemia, analogs of $1 \alpha, 25(\mathrm{OH})_{2} \mathrm{D}$ that are less calcemic but exhibit potent antiproliferative activity would be attractive as therapeutic agents. To accomplish these goals, different strategies, based on metabolism, molecular mechanism of actions, and structural modeling, have been taken to modify the structure of vitamin D molecule with the aims to improve the efficacy and decrease the toxicity of vitamin D to treat different diseases. During the past four decades, over 3,000 analogs have been synthesized. In this paper, we discuss the development and the biological analysis of a unique class of vitamin $\mathrm{D}$ analogs with a substitution at the carbon 2 of 19 -nor- $1 \alpha, 25(\mathrm{OH})_{2} \mathrm{D}_{3}$ molecule for potential application to the prevention and treatment of prostate cancer as well as other cancers.

\section{Introduction}

Prostate cancer is the most prevalent nonskin cancer among older men, with 190,000 new cases in 2010, and the second leading cause of cancer deaths among US men after lung cancer with approximately 30,000 deaths projected in 2011 [1]. Androgen deprivation is a common practice for tumors that are ineligible for or fail to respond to surgery or radiation therapy. Although the majority of men respond to androgen deprivation, the median duration of response is only about 2 years [2]. Great efforts have been made to develop new therapies to prolong the survival of patients with prostate cancer that fails to response to androgen deprivation therapy, such as docetaxel- or carbazitaxelbased chemotherapy, immunotherapy with sipuleucel-T, or abiraterone acetate. However, their effectiveness is limited to only a few months gain in survival [3].

It is now well established that the growth of prostate cells is regulated not only by androgens but also by vitamin D. Human prostate cells express vitamin D receptor (VDR) for $1 \alpha, 25$-dihydroxyvitamin $\mathrm{D}\left[1 \alpha, 25(\mathrm{OH})_{2} \mathrm{D}\right]$ (Figure 1), the active form of vitamin $\mathrm{D}$ [4]. Numerous reports have demonstrated that $1 \alpha, 25(\mathrm{OH})_{2} \mathrm{D}$ stimulates differentiation and inhibits the proliferation, invasiveness, and metastasis of prostate cancer cells [4]. These findings strongly support the use of vitamin D-based therapies for prostate cancer treatment once androgen deprivation has failed. However, the results of early clinical trials using $1 \alpha, 25(\mathrm{OH})_{2} \mathrm{D}_{3}$ (Calcitriol) indicated that the hormone caused serious hypercalcemic and hypercalciuric side effects $[5,6]$. Therefore, analogs of $1 \alpha, 25(\mathrm{OH})_{2} \mathrm{D}$ with less calcemic activity but with potent antiproliferative activity would be attractive agents.

\section{History of the Synthesis of Vitamin D Analogs}

Vitamin D was discovered a century ago because of an epidemic of a childhood bone disease, rickets [7]. It was concluded that the primary function of vitamin $D$ in humans was to enhance the intestinal absorption of calcium and phosphate, two major ingredients of bones, to maintain their serum concentrations at a sufficient level to facilitate bone calcification and other cellular functions [8]. It was later realized that vitamin $\mathrm{D}$ itself was not active and required a series of hydroxylation steps first in the liver and then 


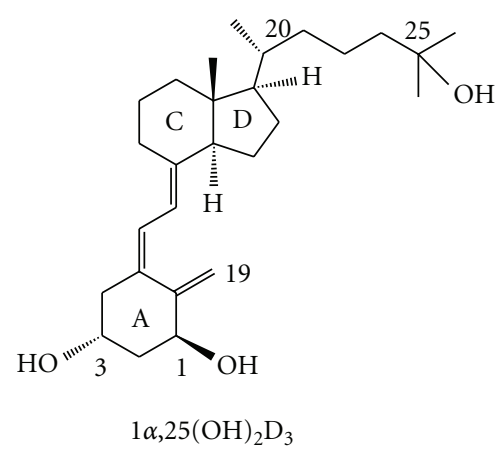

(a)

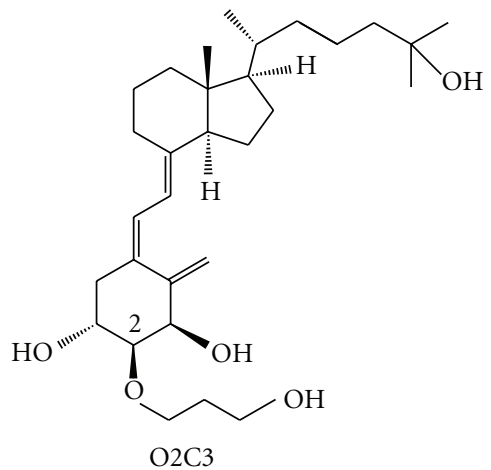

(b)

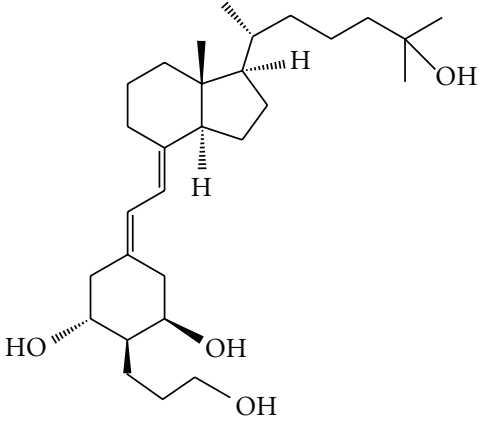

MART-10

(c)

Figure 1: Structures of $1 \alpha, 25(\mathrm{OH})_{2} \mathrm{D}_{3}, 2 \alpha$-3-hydroxypropoxy- $1 \alpha, 25(\mathrm{OH})_{2} \mathrm{D}_{3}(\mathrm{O} 2 \mathrm{C} 3)$ and 19-nor- $2 \alpha$-3-hydroxypropyl-1 $\alpha, 25(\mathrm{OH})_{2} \mathrm{D}_{3}$ (MART-10).
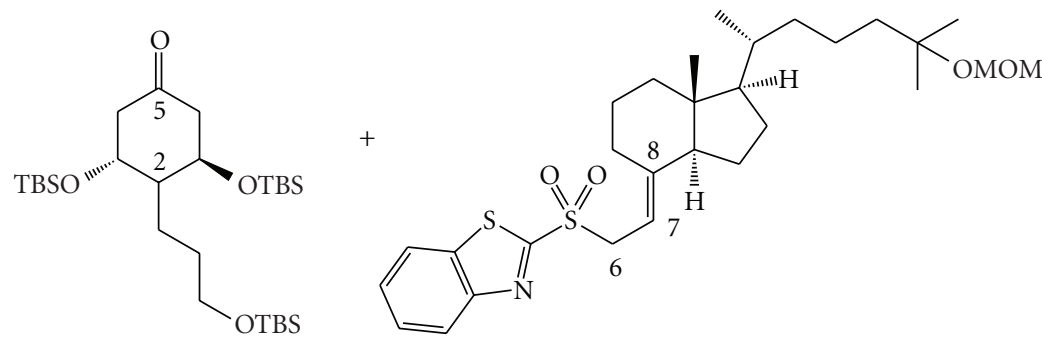

(1) LiHMDS, THF
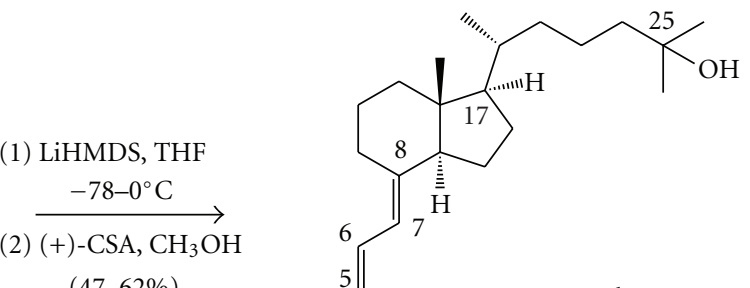

(47-62\%)

$\mathrm{HO}$<smiles>[R2]C1([R12])[C@@H](O)CC(=S)C[C@H]1O</smiles>

MART-10: $\mathrm{R}^{1}=\left(\mathrm{CH}_{2}\right)_{3} \mathrm{OH}, \mathrm{R}^{2}=\mathrm{H}$

MART-11: $\mathrm{R}^{1}=\mathrm{H}, \mathrm{R}^{2}=\left(\mathrm{CH}_{2}\right)_{3} \mathrm{OH}$

$\mathrm{R}^{2} \mathrm{R}^{2}$

FIgure 2: Julia coupling reaction between the A-ring C5 and the CD-ring C6 positions. TBS: tert-butyldimethylsilyl group as a protecting group, MOM: methoxymethyl group as a protecting group, LiHMDS: lithium hexamethyldisilazide, THF: tetrahydrofuran, $(+)-C S A:(+)-$ 10 -camphorsulfonic acid. The structures are written with steroidal numbering.

in the kidneys to form 25-hydroxyvitamin D [25(OH)D] and $1 \alpha, 25(\mathrm{OH})_{2} \mathrm{D}$, respectively, before it became active [8]. Although vitamin D was widely used in the 1940 s to treat various forms of skin diseases, such as lupus vulgaris [9], cutaneous tuberculosis [10], and psoriasis [11], it was not until late 1970s that vitamin D receptors were shown to be present in many cells and tissues which were not known to be associated with calcium and phosphorus homeostasis [12]. Subsequently, it was shown that $1 \alpha, 25(\mathrm{OH})_{2} \mathrm{D}$ was capable of inhibiting the growth of various types of cancer cells [13] and promoting the differentiation of promyelocytic leukemia cells (HL-60) to form mature macrophages [14]. The in vitro cell culture studies were followed by animal studies using xenograft mouse model and chemically induced cancer model to demonstrate the effectiveness of $1 \alpha, 25(\mathrm{OH})_{2} \mathrm{D}$ in inhibiting the tumor cell growth $[4,15,16]$. However,
$1 \alpha, 25(\mathrm{OH})_{2} \mathrm{D}$ at high doses which were usually required to inhibit tumor cell growth in vivo animal models also raised serum calcium level and decreased the body weight of the animals [16]. In human clinical trials, hypercalcemia and hypercalciuria were also found to be the major side effects of $1 \alpha, 25(\mathrm{OH})_{2} \mathrm{D}$ when it was administered systemically $[5,6]$. To overcome these drawbacks, attempts have been made to synthesize vitamin $\mathrm{D}$ analogs that retain most of the nonclassical activities of $1 \alpha, 25(\mathrm{OH})_{2} \mathrm{D}$ but have much lower calcemic activity in vivo. Several synthetic vitamin D analogs have been demonstrated to exert promising anticancer effects with reduced calcemic consequence and even greater antiproliferative activity than $1 \alpha, 25(\mathrm{OH})_{2} \mathrm{D}$ [16]. Among those vitamin D analogs, Seocalcitol (EB1089, Leo Pharmaceutical Products) is one of the most studied synthetic analogs [17-19]. A considerable number of in vitro and in 


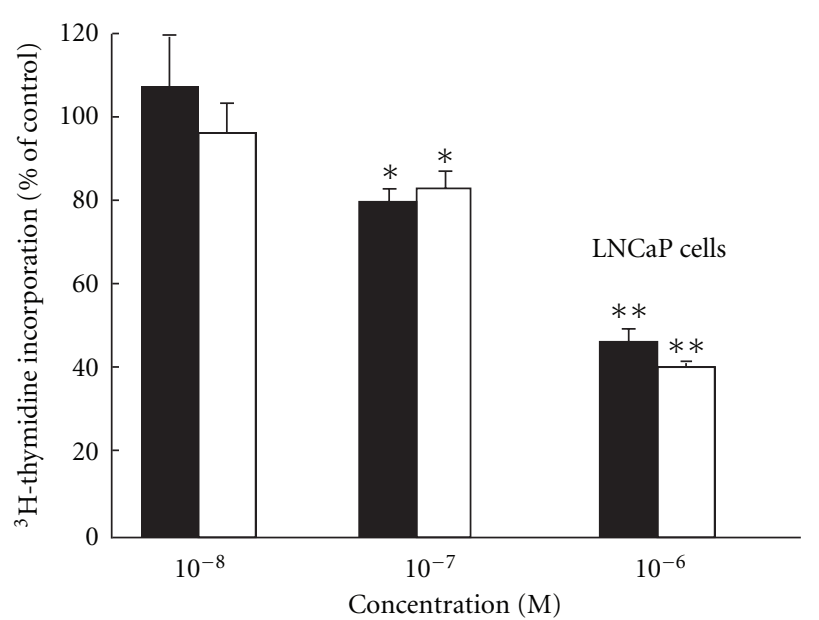

(a)

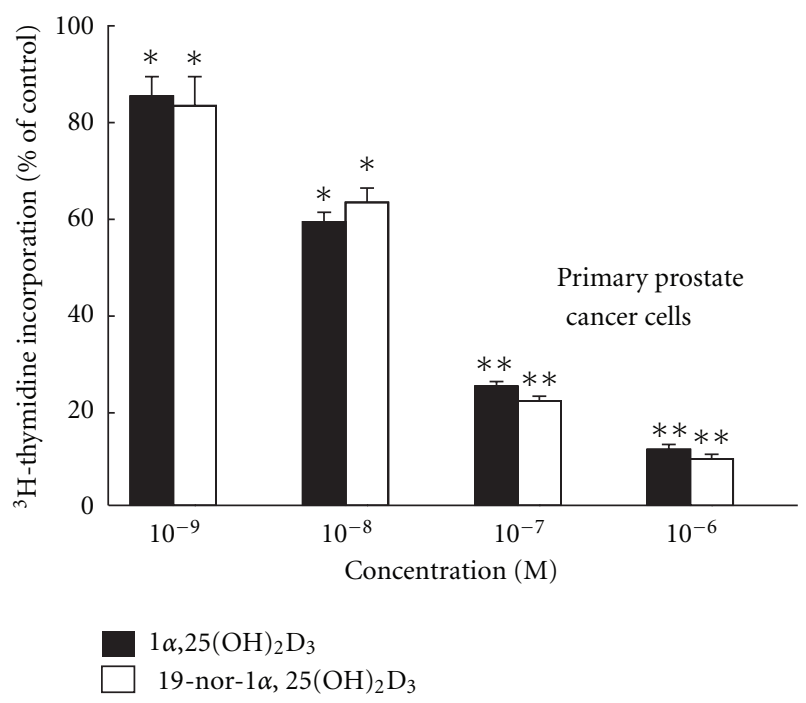

(b)

Figure 3: Comparison of the effect of $1 \alpha, 25(\mathrm{OH})_{2} \mathrm{D}_{3}$ and 19-nor$1 \alpha, 25(\mathrm{OH})_{2} \mathrm{D}_{3}$ on the ${ }^{3} \mathrm{H}$-thymidine incorporation in (a) LNCaP cells and (b) the primary cultures of prostate cancer cells. Results are presented as the means \pm SD of 5-8 determinations. There is no difference between $1 \alpha, 25(\mathrm{OH})_{2} \mathrm{D}_{3}$ and 19 -nor- $1 \alpha, 25(\mathrm{OH})_{2} \mathrm{D}_{3}$ at any dose levels examined. ${ }^{*} P<0.05,{ }^{* *} P<0.001$ versus controls.

vivo studies have been carried out with EB1089 and show that the analog is more potent than $1 \alpha, 25(\mathrm{OH})_{2} \mathrm{D}$ with respect to the regulation of cancer cell growth and differentiation, and the effect of EB1089 on calcium metabolism in vivo is approximately $50 \%$ less than that of $1 \alpha, 25(\mathrm{OH})_{2} \mathrm{D}$ [16]. The anticancer effects of EB1089 were also demonstrated in vivo in a rat model of mammary gland carcinoma without inducing hypercalcemia $[17,18]$. Similar effects were seen in an in vivo prostate cancer study where EB1089 inhibited prostate cancer cell proliferation and reduced tumorigenesis as well as tumor metastases [19]. Clinical trials with $1 \alpha$ hydroxyvitamin $\mathrm{D}_{2}$ (Hectorol) marketed by Genzyme have been conducted in hormone refractory prostate cancer patients $[20,21]$. In a phase I trial, the authors reported

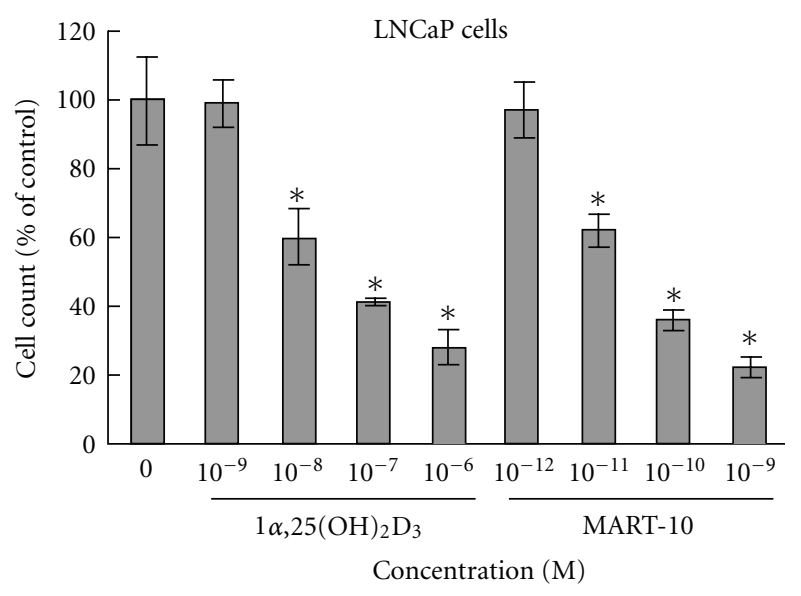

Figure 4: The dose-dependent effects of $1 \alpha, 25(\mathrm{OH})_{2} \mathrm{D}_{3}$ and MART-10 on LNCaP cell proliferation. LNCaP cells were treated with ethanol vehicle or the indicated concentrations of $1 \alpha, 25(\mathrm{OH})_{2} \mathrm{D}_{3}$ and MART-10 for one week and then trypsinized and cell counted with hemocytometer. The results are expressed as the percent of control of the means \pm SD of 3 determinations from a representative experiment. The experiment was repeated 3 times with similar results. ${ }^{*} P<0.05$ compared to the previous doses.

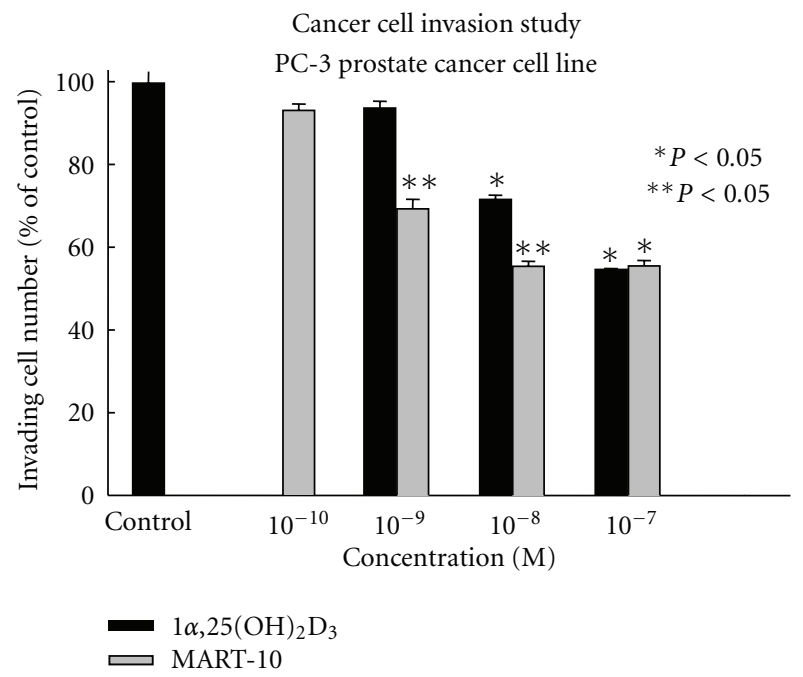

Figure 5: Effect of $1 \alpha, 25(\mathrm{OH})_{2} \mathrm{D}_{3}$, and 19-nor-2 $\alpha$-3-hydroxypropyl- $1 \alpha, 25(\mathrm{OH})_{2} \mathrm{D}_{3}$ (MART-10) on the invasion of PC-3 cells. The results are presented as the means \pm SD of 3 determinations. *Comparison between control and $1 \alpha, 25(\mathrm{OH})_{2} \mathrm{D}_{3}$ or MART-10; $* *$ Comparison between $1 \alpha, 25(\mathrm{OH})_{2} \mathrm{D}_{3}$ and MART-10.

that Hectorol was well tolerated with the main toxicities being hypercalcemia and renal insufficiency, and the side effects were reversible with drug discontinuation [20]. In a follow-up phase II study, they observed disease stability $>6$ months in $30 \%$ of the patients and the median survival of 21 months, which is higher than the 17.7 months predicted by the survival nomogram for that patient group [21]. Although the results are less than conclusive, the encouraging findings do warrant further studies with vitamin $\mathrm{D}$ analogs. 


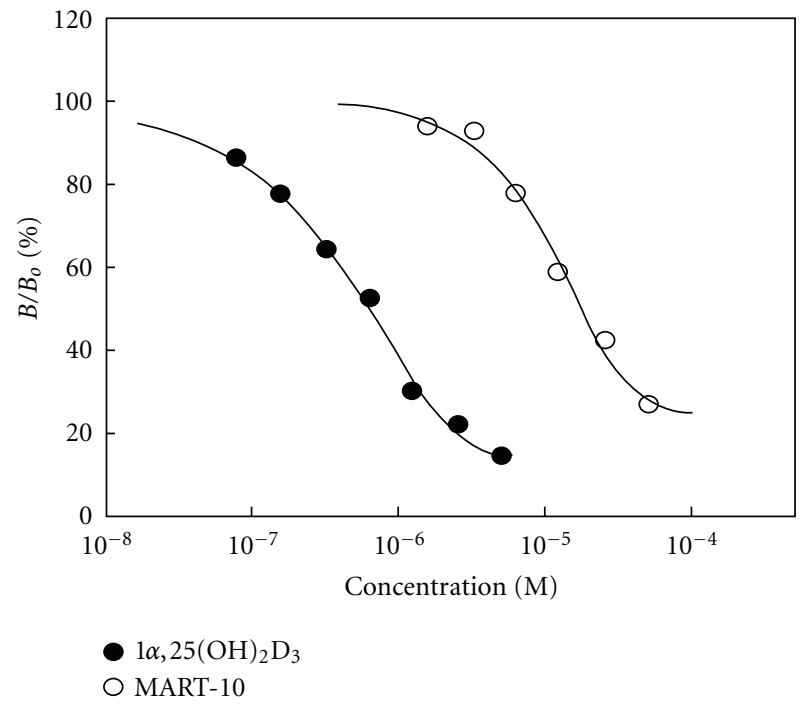

FIgURe 6: Binding of MART-10 and $1 \alpha, 25(\mathrm{OH})_{2} \mathrm{D}_{3}$ to vitamin D binding protein (DBP). The binding affinity of $1 \alpha, 25(\mathrm{OH})_{2} \mathrm{D}_{3}$ and MART-10 to vitamin-D-binding protein (DBP) was determined by the displacement of $\left[{ }^{3} \mathrm{H}\right]-25(\mathrm{OH}) \mathrm{D}_{3}$ from rat serum DBP by indicated concentrations of MART-10 and $1 \alpha, 25(\mathrm{OH})_{2} \mathrm{D}_{3}$. The results are expressed as the percentage of displaced $\left[{ }^{3} \mathrm{H}\right]-25(\mathrm{OH}) \mathrm{D}_{3}(\mathrm{~B})$ over total specific bound of $\left[{ }^{3} \mathrm{H}\right]-25(\mathrm{OH}) \mathrm{D}_{3}(\mathrm{Bo})$.

Other vitamin D analogs or structural VDR activators, such as Maxacalcitol (OCT) (Chugai Pharmaceutical Co. Ltd.) [22], 16-ene analogs (Hoffmann LaRoche, Inc.) [23], 19-nor analogs (Hoffmann LaRoche, Inc.) [24], $1 \alpha$-hydroxyvitamin $\mathrm{D}_{5}$ [25], and LG190119 (Ligand Pharmaceuticals Inc.) [26], have been developed and tested in preclinical studies. These compounds may have promise as therapeutic agents for cancer and other diseases, with fewer side effects than $1 \alpha, 25(\mathrm{OH})_{2} \mathrm{D}_{3}$ and $1 \alpha$-hydroxyvitamin $\mathrm{D}_{2}$. Other vitamin $\mathrm{D}$ analogs which have shown some promising in vitro biological activities include C-20 cyclopropylcalcitriol [27], elocalcitol [28], Gemini vitamin D analogs [29].

\section{Development of the Less Calcemic 19-Norvitamin D Analogs}

19-Norvitamin D compounds in which the ring A methylene group on C-19 is replaced with two hydrogen atoms were known to be in existence in 1983 when 19-nor-10ketovitamin $\mathrm{D}$ derivatives were first isolated and identified from a mixture of vitamin $\mathrm{D}$ or $25(\mathrm{OH}) \mathrm{D}$ solution incubated with bovine rumen microbes [30]. Later, 19nor- $1 \alpha, 25(\mathrm{OH})_{2} \mathrm{D}_{3}$ was synthesized by Perlman et al. to study the structure-activity relationship of $1 \alpha, 25(\mathrm{OH})_{2} \mathrm{D}_{3}$ molecule [31]. They reported that this analog induced the differentiation of human leukemia HL-60 cells similar to $1 \alpha, 25(\mathrm{OH})_{2} \mathrm{D}_{3}$ with little or no calcemic activity [31]. The findings led to the synthesis of 19 -nor- $1 \alpha, 25(\mathrm{OH})_{2} \mathrm{D}_{2}$ and the evaluation of its activity by Slatopolsky et al. [32]. Both 19-nor- $1 \alpha, 25(\mathrm{OH})_{2} \mathrm{D}_{2}$ and 19 -nor- $1 \alpha, 25(\mathrm{OH})_{2} \mathrm{D}_{3}$ have potency similar to $1 \alpha, 25(\mathrm{OH})_{2} \mathrm{D}_{3}$ in inducing $\mathrm{CYP} 24 \mathrm{~A} 1$ promoter activity in a transcription assay and in suppressing parathyroid hormone secretion in hemodialysis patients with secondary hyperparathyroidism, without inducing hypercalcemia or hyperphosphatemia [30-33]. Today, 19-nor$1 \alpha, 25(\mathrm{OH})_{2} \mathrm{D}_{2}$, also called Zemplar or paricalcitol, is an FDA-approved drug for the treatment of secondary hyperparathyroidism. Subsequently, different modifications of the A-ring, including the synthesis of C-2 modified 19-norvitamin D compounds, were accomplished by a significant number of synthetic organic chemists [34-41].

The first synthesis of 19-norvitamin D reported by DeLuca's group in 1990 is a direct synthesis starting from 25-hydroxyvitamin $\mathrm{D}_{3}$ [31]. Subsequently, a convergent synthetic route was described by the same group, and the method has become one of the standard ones for the synthesis of new 19-norvitamin D analogs [42]. The con-vergent method consists of a coupling reaction between an A-ring phosphine oxide with a C1-C7 carbon unit and an 8-ketoCD-ring with a C17 side chain such as 25-hydroxy Grundmann's ketone.

During the past decade, systematic synthesis of vitamin $\mathrm{D}_{3}$ analogs with $\mathrm{C} 2$-modification has been attempted, and a number of C2-modified analogs with a greater VDR agonistic activity than $1 \alpha, 25(\mathrm{OH})_{2} \mathrm{D}_{3}$ have been successfully synthesized [34, 35, 42-44]. For example, a substitution with $2 \alpha$ methyl, $2 \alpha$-(3-hydroxypropyl), or $2 \alpha$-(3-hydroxypropoxy) group increased its binding affinity for the VDR two- to fourfold compared to $1 \alpha, 25(\mathrm{OH})_{2} \mathrm{D}_{3}$ [43-45]. Similarly, several highly potent VDR antagonists, which belong to a series of TEI-9647 analogs with C2 $\alpha$ functionalization as well as the 24-alkyl modification on the lactone ring, have been synthesized [46]. The mechanism of the enhanced C2 $\alpha$-effects on VDR binding affinity has been revealed by an X-ray cocrystallographic analysis of the VDR-ligand complexes [47]. The study shows that the terminal hydroxy group of $2 \alpha$-(3hydroxypropyl) or $2 \alpha$-(3-hydroxypropoxy) substituent plays an important role in expelling the water molecules in the ligand binding domain of the VDR to form hydrogen bonds with arginine-274 residue of the VDR molecule to stabilize the VDR-ligand complex [47]. Knowing the advantage of modifying $1 \alpha, 25(\mathrm{OH})_{2} \mathrm{D}_{3}$ molecule with "2-substitution" to enhance VDR binding affinity and "19-demethylenation" to eliminate calcemic potential, we, therefore, set forth to synthesize $\mathrm{C} 2$-substituted 19 -nor- $1 \alpha, 25(\mathrm{OH})_{2} \mathrm{D}_{3}$ analogs using the convergent synthetic approach developed by DeLuca's laboratory [42]. However, during the synthesis of 19-nor- $2 \alpha-$ 3 -hydroxypropyl- $1 \alpha, 25(\mathrm{OH})_{2} \mathrm{D}_{3}$ (MART-10) and 19-nor$2 \beta$-3-hydroxypropyl- $1 \alpha, 25(\mathrm{OH})_{2} \mathrm{D}_{3}$ (MART-11), we quickly realized that the typical coupling reaction between the 2substituted 19-nor-A-ring part and the 8-keto-CD-ring part, that is, C7-C8 connection based on the Horner-WadsworthEmmons reaction, was problematic because of the large 1,2steric repulsion between $1 \alpha$-siloxy and the phenyl groups on phosphorus atom present in the oxaphosphetane transition state [34]. We decided to connect one of the double bonds of the target diene of MART-10/MART-11 between the C5 (Aring) and C6 (two carbons elongated CD-ring from the 8keto group) positions using the Julia coupling approach, and the reactions turned out to be successful (Figure 2). Finally, 


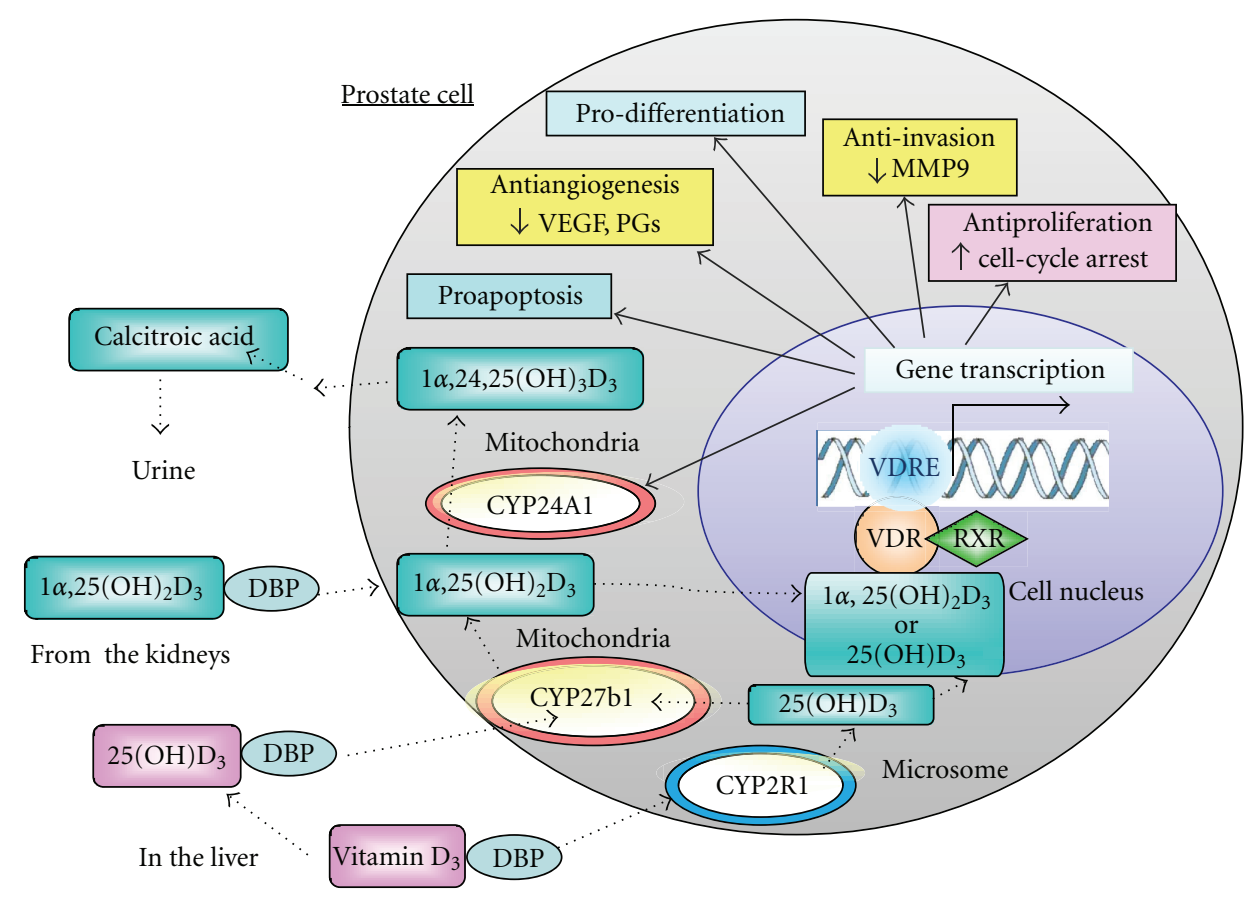

FIGURE 7: Metabolism and the nonclassical actions of vitamin D in prostate cells. Prostate cells express vitamin D 25-hydroxylase (25-OHase, or CYP2R1, a microsomal enzyme), $1 \alpha$-OHase (or CYP27B1, a mitochondrial enzyme), and 24-OHase (or CYP24A1, a mitochondrial enzyme) and, therefore, are capable of synthesizing $1 \alpha, 25(\mathrm{OH})_{2} \mathrm{D}_{3}$ from vitamin $\mathrm{D}_{3}$. Binding of $1 \alpha, 25(\mathrm{OH})_{2} \mathrm{D}_{3}$ or $25(\mathrm{OH}) \mathrm{D}_{3}$ to the vitamin $\mathrm{D}$ receptor (VDR) causes the VDR to heterodimerize with the retinoid X receptor (RXR). The VDR-RXR heterodimer binds to specific vitamin $\mathrm{D}$ response elements in the promoter region of vitamin-D-responsive genes and induces gene transcription. The gene products include proteins involved in its own metabolism (CYP24A1), cell-cycle arrest, apoptosis, differentiation, anti-invasion, antiangiogenesis, and many other actions.

the target products were separated using a reversed phase HPLC to obtain two diastereomers, MART-10 ( $2 \alpha$-form) and MART-11 (2 $\beta$-form) [48].

The MART-10 and MART-11 obtained were then studied for their VDR binding property using a calf thymus vitamin $\mathrm{D}$ receptor preparation and HL-60 differentiation potency. We found that MART-10 and MART-11 had a binding affinity equal to $100 \%$ and $3 \%$ of the parent hormone $1 \alpha, 25(\mathrm{OH})_{2} \mathrm{D}_{3}$, respectively. However, we observed a $36-$ fold and 7-fold greater activity in the induction of HL-60 cell differentiation by MART-10 and MART-11, respectively, than by $1 \alpha, 25(\mathrm{OH})_{2} \mathrm{D}_{3}[35,49]$. The discrepancy between VDR binding and differentiation activity can be explained at least in part by a greater ability in recruiting coactivators, such as hTIF-2 and hSRC-1, by MART-10 and MART-11 than by $1 \alpha, 25(\mathrm{OH})_{2} \mathrm{D}_{3}$ as determined by a high-throughput screening method developed in our laboratory to study the interaction between human VDR and cofactors [50].

\section{The Antiproliferative Activity of 19-Norvitamin D Analogs in Prostate Cells}

The antiproliferative activity of 19-norvitamin D analogs was first studied in LNCaP prostate cancer cells and in primary cultures of prostate cancer cells using 19 -nor- $1 \alpha, 25(\mathrm{OH})_{2} \mathrm{D}_{2}$ and 19 -nor- $1 \alpha, 25(\mathrm{OH})_{2} \mathrm{D}_{3}[50,51]$. It was reported that 19 -nor- $1 \alpha, 25(\mathrm{OH})_{2} \mathrm{D}_{2}$ had antiproliferative activity comparable to $1 \alpha, 25(\mathrm{OH})_{2} \mathrm{D}_{3}$, as determined by ${ }^{3} \mathrm{H}$-thymidine incorporation [51]. Similarly, 19-nor- $1 \alpha, 25(\mathrm{OH})_{2} \mathrm{D}_{3}$ was found to be equipotent to $1 \alpha, 25(\mathrm{OH})_{2} \mathrm{D}_{3}$ in the primary cultures of prostate cancer cells and LNCaP prostate cancer cells (Figure 3) [52]. After we obtained a series of 19nor- $1 \alpha, 25(\mathrm{OH})_{2} \mathrm{D}_{3}$ analogs modified at C-2 position with different hydrocarbon moieties, we began to study their antiproliferative activity in $\mathrm{PZ}-\mathrm{HPV}-7$ prostate cells, a cell line derived from the epithelial zone of a normal prostate and obtained from ATCC. Among them, 19-nor- $2 \alpha-3$-hydroxypropyl- $1 \alpha, 25(\mathrm{OH})_{2} \mathrm{D}_{3}$ (MART-10) and 19-nor-2 $\beta$-3hydroxypropyl- $1 \alpha, 25(\mathrm{OH})_{2} \mathrm{D}_{3}$ (MART-11) were found to be about 500 - to 1,000 -fold more active than $1 \alpha, 25(\mathrm{OH})_{2} \mathrm{D}_{3}$ [53].

Comparison of the inhibitory effect of MART-10 with $1 \alpha, 25(\mathrm{OH})_{2} \mathrm{D}_{3}$ on the cellular proliferation was then carried out in androgen-dependent LNCaP and androgen-independent PC-3 prostate cancer cells by hemocytometer cell counting. Similar to the findings using PZ-HPV-7 cells, MART10 is about 1,000 -fold more active than $1 \alpha, 25(\mathrm{OH})_{2} \mathrm{D}_{3}$ in inhibiting LNCaP (Figure 4) [54] and PC-3 prostate cancer cell proliferation (D. Iglesias-Gato et al., unpublished data).

\section{Metabolism of MART-10 by 24-Hydroxylase (24-OHase or CYP24A1)}

CYP24A1 is one of the three major enzymes involved in the metabolism of vitamin $\mathrm{D}$ endocrine system. The gene 
encoding this enzyme is highly inducible by $1 \alpha, 25(\mathrm{OH})_{2} \mathrm{D}_{3}$ or its analogs, and, therefore, the induction of this gene has been used as an index for the biological potency of new analogs $[55,56]$. Most importantly, CYP24A1 serves as a principle mechanism to terminate the biological actions of $1 \alpha, 25(\mathrm{OH})_{2} \mathrm{D}_{3}$ or its analogs through 24-hydroxylationdependent catabolic pathway [57]. Because of this important role, specific inhibitors of CYP24A1 have been developed and used to enhance and prolong the actions of the natural hormone [57]. Alternatively, analogs which are more resistant to the catabolic degradation of CYP24A1 will have longer halflife and potentially more bioavailablity than $1 \alpha, 25(\mathrm{OH})_{2} \mathrm{D}_{3}$.

In a series of experiments comparing the expression of CYP24A1 in response to $1 \alpha, 25(\mathrm{OH})_{2} \mathrm{D}_{3}$ and MART-10 treatment in LNCaP and PC-3 prostate cancer cells, we observed that MART-10 was capable of inducing CYP24A1 expression at a lower concentration and to a greater extent [54] and with a longer duration than $1 \alpha, 25(\mathrm{OH})_{2} \mathrm{D}_{3}$ (D. Iglesias-Gato et al., unpublished observation). The longer duration suggests that MART-10 is more resistant to CYP24A1 degradation. To find out whether this was the case, we then used a cell-free CYP24A1 reconstituted system [54] to determine the $k_{\text {cat }} / K_{m}$ value, an indicator of enzyme susceptibility, of MART-10 or $2 \alpha$-(3-hydroxypropoxy)- $1 \alpha, 25(\mathrm{OH})_{2} \mathrm{D}_{3} \quad(\mathrm{O} 2 \mathrm{C} 3)$ (Figure 1) used as a substrate. We found that MART-10 had a $k_{\text {cat }} / K_{m}$ of 0.33 which is about $1 / 10$ of what was found with $\mathrm{O} 2 \mathrm{C} 3$ $\left(k_{\text {cat }} / K_{m}=3.0\right)$. Since the $k_{\text {cat }} / K_{m}$ for O2C3 is about $1 / 50$ of $1 \alpha, 25(\mathrm{OH})_{2} \mathrm{D}_{3}$ [58], the $k_{\text {cat }} / K_{m}$ for MART-10 is about $1 / 500$ of $1 \alpha, 25(\mathrm{OH})_{2} \mathrm{D}_{3}$. The $k_{\text {cat }} / K_{m}$ data suggest that the addition of 3-hydroxypropyl group at carbon 2 in the MART10 molecule may hinder the contact of the side-chain of MART-10 molecule to the heme group of CYP24A1 and results in a very poor 24-hydroxylation and, in turn, much less degradation of MART-10 by CYP24A1. The conclusion is supported by a docking model of MART-10 sit inside the substrate-binding pocket of the human CYP24A1 (Personal communication with Drs. Yamamoto and Sakaki).

\section{MART-10 Is a More Potent Inhibitor of Cancer Cell Invasion}

In addition to its higher activity in inhibiting prostate cancer cell proliferation, MART-10 is about 10-fold more active than $1 \alpha, 25(\mathrm{OH})_{2} \mathrm{D}_{3}$ in inhibiting PC-3 cell invasion (Figure 5) [53]. Similar results were obtained with 19-nor$2 \beta$-3-hydroxypropyl- $1 \alpha, 25(\mathrm{OH})_{2} \mathrm{D}_{3}$ (unpublished observation). MART-10 also exhibited a greater downregulation of matrix metalloproteinase-9 (MMP-9) expression at both the transcriptional and translational levels (D. Iglesias-Gato et al., unpublished observation). Since MMP-9 is an enzyme involved in the cell invasion pathway [59, 60], the greater downregulation of MMP-9 activity may be responsible for the more potent anti-invasion effect observed in the presence of MART-10. In turn, the greater effect on MMP9 gene expression and the expression of CYP24A1 and genes involved in cell proliferation may be due to its more profound VDR transactivation activity in prostate cancer cells $[54,61]$.
TABLE 1: Comparison of biological activity between $1 \alpha, 25(\mathrm{OH})_{2} \mathrm{D}_{3}$ and MART-10 in prostate cancer cells.

\begin{tabular}{lcccc}
\hline & $\begin{array}{c}\text { Anti- } \\
\text { proliferation }\end{array}$ & $\begin{array}{c}\text { Anti- } \\
\text { invasion }\end{array}$ & $\begin{array}{c}\text { CYP24A1, } \\
K_{\text {cat }} / K_{m}\end{array}$ & $\begin{array}{c}\text { DBP } \\
\text { Binding }\end{array}$ \\
\hline $1 \alpha, 25(\mathrm{OH})_{2} \mathrm{D}_{3}$ & 1 & 1 & 1 & 1 \\
MART-10 & 1,000 & 100 & $1 / 500$ & $1 / 25$ \\
\hline
\end{tabular}

\section{MART-10 Binds to Vitamin-D-Binding Protein (DBP) with a Lower Affinity Than $1 \alpha, 25(\mathrm{OH})_{2} \mathrm{D}_{3}$}

The bioavailability of MART-10 in circulation was examined by measuring its binding affinity to serum DBP $(\mathrm{Kd}$, defined as the concentration of $1 \alpha, 25(\mathrm{OH})_{2} \mathrm{D}_{3}$ or MART-10 at which a $50 \%$ reduction in $\left[{ }^{3} \mathrm{H}\right]-25(\mathrm{OH}) \mathrm{D}_{3}$ binding to DBP was observed). The Kds for MART-10 and $1 \alpha, 25(\mathrm{OH})_{2} \mathrm{D}_{3}$ are $17.5 \mu \mathrm{M}$ and $0.67 \mu \mathrm{M}$, respectively, indicating that the binding affinity of MART-10 for DBP is about 25-fold less than that for $1 \alpha, 25(\mathrm{OH})_{2} \mathrm{D}_{3}$ (Figure 6) [54]. The lower DBP binding affinity for MART-10 will allow more MART-10 to be translocated into the target cells, including the prostate.

\section{Conclusion}

Vitamin D has been discovered as an antirachitic agent for almost a century. For more than half a century since its discovery, vitamin D was believed to be involved only in calcium and phosphate homeostasis. The realization that vitamin $\mathrm{D}$ (vitamin $\mathrm{D}_{2}$ and vitamin $\mathrm{D}_{3}$ ) itself was not active and required two successive hydroxylation steps to produce its active form, $1 \alpha, 25(\mathrm{OH})_{2} \mathrm{D}_{3}$, led to the finding in 1979 that VDR was present in many tissues not related to calcium and phosphate metabolism. Subsequently, many nonclassical actions of $1 \alpha, 25(\mathrm{OH})_{2} \mathrm{D}_{3}$ were revealed, including antiproliferation, anti-invasion, proapoptosis, prodifferentiation, immune regulation, and so forth, (Figure 7). Although $1 \alpha, 25(\mathrm{OH})_{2} \mathrm{D}_{3}$ exhibited potent antitumor effects on prostate cancer models, hypercalcemia and hypercalciuria side effects were quickly realized in animal models and human clinical trials. The lethal side effects, thus, limit the application of $1 \alpha, 25(\mathrm{OH})_{2} \mathrm{D}_{3}$ clinically. Consequently, several thousand vitamin $\mathrm{D}$ analogs were synthesized with an intention to eliminate or lessen the side effects and at the same time to enhance their antitumor activity. So far, none of the analogs have shown clinically satisfactory results. In this paper we describe the synthesis of a novel analog of $1 \alpha, 25(\mathrm{OH})_{2} \mathrm{D}_{3}$, called MART-10 and present in vitro data using normal, androgen-dependent LNCaP, and androgen-independent PC-3 cell culture models. Comparing to $1 \alpha, 25(\mathrm{OH})_{2} \mathrm{D}_{3}$, MART-10 is 10 times more active in stimulating VDR transactivation in LNCaP cells, about 500to 1000 -fold more active in inhibiting the proliferation of these three types of prostate cells, 10 times more potent in inhibiting PC-3 invasion, at least 500-fold more resistant to CYP24A1-dependent degradation and has about 25-fold lower binding affinity to DBP (Table 1). In addition, MART10 did not raise serum calcium when it was injected into 
rats [D. Iglesias-Gato et al., unpublished observation]. The unique properties of MART-10 suggest that this analog has a potential as a new regimen for prostate cancer treatments through all stages of the disease.

\section{Abbreviations}

$\begin{array}{ll}1 \alpha, 25(\mathrm{OH})_{2} \mathrm{D}_{3}: & 1 \alpha, 25 \text {-dihydroxyvitamin } \mathrm{D}_{3} \\ \text { VDR: } & \text { Vitamin D receptor } \\ \text { DBP: } & \text { Vitamin D binding protein } \\ \text { MMP-9: } & \text { Matrix metalloproteinase- } 9 \\ \text { O2C3: } & 2 \alpha \text {-(3-hydroxypropoxy)-1 } \alpha, 25(\mathrm{OH})_{2} \mathrm{D}_{3} \\ \text { MART-10: } & 19 \text {-nor- } \alpha \text { - }(3 \text {-hydroxypropyl)- } \\ & 1 \alpha, 25(\mathrm{OH})_{2} \mathrm{D}_{3} \\ \text { MART-11: } & 19 \text {-nor- } 2 \beta-(3 \text {-hydroxypropyl)- } \\ & 1 \alpha, 25(\mathrm{OH})_{2} \mathrm{D}_{3} .\end{array}$

\section{References}

[1] A. Jemal, R. Siegel, E. Ward, Y. Hao, J. Xu, and M. J. Thun, "Cancer statistics, 2009," CA Cancer Journal for Clinicians, vol. 59, no. 4, pp. 225-249, 2009.

[2] R. S. Kirby, "Recent advances in the medical management of prostate cancer," British Journal of Clinical Practice, vol. 50, no. 2, pp. 88-93, 1996.

[3] H. Beltran, T. M. Beer, M. A. Carducci et al., "New therapies for castration-resistant prostate cancer: efficacy and safety," European Urology, vol. 60, no. 2, pp. 279-290, 2011.

[4] G. J. Miller, "Vitamin D and prostate cancer: biologic interactions and clinical potentials," Cancer and Metastasis Reviews, vol. 17, no. 4, pp. 353-360, 1999.

[5] J. L. Osborn, G. G. Schwartz, D. C. Smith, R. Bahnson, R. Day, and D. L. Trump, "Phase II trial of oral 1,25-dihydroxyvitamin D (calcitriol) in hormone refractory prostate cancer," Urologic Oncology, vol. 1, no. 5, pp. 195-198, 1995.

[6] C. Gross, T. Stamey, S. Hancock, and D. Feldman, "Treatment of early recurrent prostate cancer with 1,25-dihydroxyvitamin D3 (calcitriol)," Journal of Urology, vol. 159, no. 6, pp. 20352040, 1998.

[7] E. V. McCollum, N. Simmonds, J. E. Becker, P. G. Shipley, and R. W. Bunting, "Studies on experimental rickets. XXI. An experimental demonstration of the existence of a vitamin which promotes calcium deposition," Journal of Biological Chemistry, vol. 53, pp. 293-312, 1922.

[8] H. F. DeLuca and H. K. Schnoes, "Metabolism and mechanism of action of vitamin D," Annual Review of Biochemistry, vol. 45, pp. 631-666, 1976.

[9] FS Airey, "Vitamin D as a remedy for lupus vulgaris," Medical World, vol. 64, pp. 807-810, 1946.

[10] J. Charpy, G. B. Dowling et al., "Vitamin D in cutaneous tuberculosis," Lancet, vol. 2, no. 6472, p. 398, 1947.

[11] L. J. Holcik, "Treatment of psoriasis with large doses of vitamin D2," Ceskoslovenska Dermatologie, vol. 24, no. 4, pp. 145149, 1949.

[12] W. E. Stumpf, M. Sar, F. A. Reid et al., "Target cells for 1,25-dihydroxyvitamin D3 in intestinal tract, stomach, kidney, skin, pituitary, and parathyroid," Science, vol. 206, no. 4423, pp. 1188-1190, 1979.

[13] K. Colston, M. Hirst, and D. Feldman, "Organ distribution of the cytoplasmic 1,25-dihydroxycholecalciferol receptor in various mouse tissues," Endocrinology, vol. 107, no. 6, pp. 19161922, 1980.
[14] E. Abe, C. Miyaura, and H. Sakagami, "Differentiation of mouse myeloid leukemia cells induced by $1 \alpha, 25$-dihydroxyvitamin $\mathrm{D}_{3}$," Proceedings of the National Academy of Sciences of the United States of America, vol. 78, no. 8, pp. 4990-4994, 1981.

[15] T. C. Chen and M. F. Holick, "Vitamin D and prostate can-cer prevention and treatment," Trends in Endocrinology and Metabolism, vol. 14, no. 9, pp. 423-430, 2003.

[16] A. J. Brown and E. Slatopolsky, "Vitamin D analogs: therapeutic applications and mechanisms for selectivity," Molecular Aspects of Medicine, vol. 29, no. 6, pp. 433-452, 2008.

[17] K. W. Colston, A. G. Mackay, S. Y. James, L. Binderup, S. Chander, and R. C. Coombes, "EB1089: a new vitamin D analogue that inhibits the growth of breast cancer cells in vivo and in vitro," Biochemical Pharmacology, vol. 44, no. 12, pp. 22732280, 1992.

[18] M. E. Valrance, A. H. Brunet, and J. Welsh, "Vitamin D receptor-dependent inhibition of mammary tumor growth by EB1089 and ultraviolet radiation in vivo," Endocrinology, vol. 148, no. 10, pp. 4887-4894, 2007.

[19] V. Bhatia, M. K. Saini, X. Shen et al., "EB1089 inhibits the parathyroid hormone-related protein-enhanced bone metastasis and xenograft growth of human prostate cancer cells," Molecular Cancer Therapeutics, vol. 8, no. 7, pp. 1787-1798, 2009.

[20] G. Liu, K. Oettel, G. Ripple et al., "Phase I trial of $1 \alpha$-hydroxyvitamin D2 in patients with hormone refractory prostate cancer," Clinical Cancer Research, vol. 8, no. 9, pp. 2820-2827, 2002.

[21] G. Liu, G. Wilding, M. J. Staab et al., "Phase II study of $1 \alpha-$ hydroxyvitamin D2 in the treatment of advanced androgenindependent prostate cancer," Clinical Cancer Research, vol. 9, no. 11, pp. 4077-4083, 2003.

[22] J. Abe, M. Morikawa, K. Miyamoto et al., "Synthetic analogues of vitamin D3 with an oxygen atom in the side chain skeleton. A trial of the development of vitamin D compounds which exhibit potent differentiation-inducing activity without inducing hypercalcemia," FEBS Letters, vol. 226, no. 1, pp. 5862, 1987.

[23] J. Y. Zhou, A. W. Norman, M. Lübbert, E. D. Collins, M. R. Uskokovic, and H. P. Koeffler, "Novel vitamin D analogs that modulate leukemic cell growth and differentiation with little effect on either intestinal calcium absorption or bone calcium mobilization," Blood, vol. 74, no. 1, pp. 82-93, 1989.

[24] H. Asou, M. Koike, E. Elstner et al., "19-nor vitamin-D analogs: a new class of potent inhibitors of proliferation and inducers of differentiation of human myeloid leukemia cell lines," Blood, vol. 92, no. 7, pp. 2441-2449, 1998.

[25] R. G. Mehta, R. M. Moriarty, R. R. Mehta, R. Penmasta, G. Lazzaro, and A. Constantinou, "Prevention of preneoplastic mammary lesion development by a novel vitamin $\mathrm{D}$ analogue, $1 \alpha$-hydroxyvitamin D5," Journal of the National Cancer Institute, vol. 89, no. 3, pp. 212-218, 1997.

[26] M. F. Boehm, P. Fitzgerald, A. Zou et al., "Novel nonsecosteroidal vitamin D mimics exert VDR-modulating activities with less calcium mobilization than 1,25-dihydroxyvitamin D3," Chemistry and Biology, vol. 6, no. 5, pp. 265-275, 1999.

[27] M. R. Uskokovic, P. Manchand, S. Marczak et al., "C-20 cyclopropyl vitamin D3 analogs," Current Topics in Medicinal Chemistry, vol. 6, no. 12, pp. 1289-1296, 2006.

[28] L. Adorini, G. Penna, S. Amuchastegui et al., "Inhibition of prostate growth and inflammation by the vitamin D3 receptor agonist BXL-628 (elocalcitol)," Journal of Steroid Biochemistry and Molecular Biology, vol. 103, no. 3-5, pp. 689-693, 2007. 
[29] T. Saito, R. Okamoto, T. Haritunians et al., "Novel Gemini vitamin D3 analogs have potent antitumor activity," Journal of Steroid Biochemistry and Molecular Biology, vol. 112, no. 1-3, pp. 151-156, 2008.

[30] J. L. Napoli, J. L. Sommerfeld, B. C. Pramanik et al., “19-Nor10-ketovitamin D derivatives: unique metabolites of vitamin D3, vitamin D2, and 25-hydroxyvitamin D3," Biochemistry, vol. 22, no. 15, pp. 3636-3640, 1983.

[31] K. L. Perlman, R. R. Sicinski, H. K. Schnoes, and H. F. DeLuca, " $1 \alpha, 25$-Dihydroxy-19-nor-vitamin $\mathrm{D}_{3}$, a novel vitamin D-related compound with potential therapeutic activity," Tetrahedron Letters, vol. 31, no. 13, pp. 1823-1824, 1990.

[32] E. Slatopolsky, J. Finch, C. Ritter et al., "A new analog of calcitriol, 19-Nor-1,25- $(\mathrm{OH})_{2} \mathrm{D}_{2}$, suppresses parathyroid hormone secretion in uremic rats in the absence of hypercalcemia," American Journal of Kidney Diseases, vol. 26, no. 5, pp. 852-860, 1995.

[33] F. Llach, G. Keshav, M. V. Goldblat et al., "Suppression of parathyroid hormone secretion in hemodialysis patients by a novel vitamin D analogue: 19-nor-1,25-dihydroxyvitamin D2," American Journal of Kidney Diseases, vol. 32, no. 2, supplement 2, pp. S48-S54, 1998.

[34] R. R. Sicinski, P. Rotkiewicz, A. Kolinski et al., "2-Ethyl and 2ethylidene analogues of 1 $\alpha, 25$-dihydroxy-19-norvitamin D3: synthesis, conformational analysis, biological activities, and docking to the modeled rVDR ligand binding domain," Journal of Medicinal Chemistry, vol. 45, no. 16, pp. 3366-3380, 2002.

[35] K. Ono, A. Yoshida, N. Saito et al., "Efficient synthesis of 2modified $1 \alpha, 25$-dihydroxy-19-norvitamin D3 with Julia olefination: high potency in induction of differentiation on HL60 cells," Journal of Organic Chemistry, vol. 68, no. 19, pp. 7407-7415, 2003.

[36] A. Kittaka, N. Saito, S. Honzawa et al., "Creative synthesis of novel vitamin D analogs for health and disease," Journal of Steroid Biochemistry and Molecular Biology, vol. 103, no. 3-5, pp. 269-276, 2007.

[37] A. Toyoda, H. Nagai, T. Yamada et al., "Novel synthesis of 1 $\alpha$,25-dihydroxy-19-norvitamin $\mathrm{D}$ from 25-hydroxyvitamin D," Tetrahedron, vol. 65, no. 48, pp. 10002-10008, 2009.

[38] T. Hanazawa, T. Wada, T. Masuda, S. Okamoto, and F. Sato, "Novel synthetic approach to 19-nor-1 $\alpha, 25$-dihydroxyvitamin $\mathrm{D}_{3}$ and its derivatives by Suzuki-Miyaura coupling in solution and on solid support," Organic Letters, vol. 3, no. 24, pp. 39753977, 2001.

[39] P. Huang, K. Sabbe, M. Pottie, and M. Vandewalle, "A novel synthesis of 19-nor 1 $\alpha, 25$-dihydroxyvitamin D3 and related analogues," Tetrahedron Letters, vol. 36, no. 45, pp. 8299-8302, 1995.

[40] M. Shimizu, Y. Miyamoto, H. Takaku et al., "2-Substituted-16ene-22-thia-1 $\alpha, 25$-dihydroxy-26,27-dimethyl-19-norvitamin D3 analogs: synthesis, biological evaluation, and crystal structure," Bioorganic and Medicinal Chemistry, vol. 16, no. 14, pp. 6949-6964, 2008.

[41] A. Glebocka, R. R. Sicinski, L. A. Plum, M. Clagett-Dame, and H. F. DeLuca, "New 2-alkylidene 1 $\alpha, 25$-dihydroxy-19norvitamin $\mathrm{D}_{3}$ analogues of high intestinal activity: synthesis and biological evaluation of 2-(3'-alkoxypropylidene) and 2-(3'-hydroxypropylidene) derivatives," Journal of Medicinal Chemistry, vol. 49, no. 10, pp. 2909-2920, 2006.

[42] K. L. Perlman, R. E. Swenson, H. E. Paaren, H. K. Schnoes, and H. F. DeLuca, "Novel synthesis of 19-nor-vitamin D compounds," Tetrahedron Letters, vol. 32, no. 52, pp. 7663-7666, 1991.
[43] N. Saito, S. Honzawa, and A. Kittaka, "Recent results on A-ring modification of $1 \alpha, 25$-dihydroxyvitamin $\mathrm{D}_{3}$ : design and synthesis of VDR-agonists and antagonists with high biological activity," Current Topics in Medicinal Chemistry, vol. 6, no. 12, pp. 1273-1288, 2006.

[44] N. Saito, Y. Suhara, M. Kurihara et al., "Design and efficient synthesis of $2 \alpha$-( $\omega$-hydroxyalkoxy)- $1 \alpha, 25$-dihydroxyvitamin D3 analogues, including 2-epi-ED-71 and their 20-epimers with HL-60 cell differentiation activity," Journal of Organic Chemistry, vol. 69, no. 22, pp. 7463-7471, 2004.

[45] E. Takahashi, K. Nakagawa, Y. Suhara et al., "Biological activities of $2 \alpha$-substituted analogues of $1 \alpha, 25$-dihydroxyvitamin D3 in transcriptional regulation and human promyelocytic leukemia (HL-60) cell proliferation and differentiation," Biological and Pharmaceutical Bulletin, vol. 29, no. 11, pp. 22462250, 2006.

[46] N. Saito, T. Matsunaga, H. Saito et al., "Further synthetic and biological studies on vitamin D hormone antagonists based on C24-alkylation and C2 $\alpha$-functionalization of 25-dehydro$1 \alpha$ - hydroxyvitamin D3-26,23-lactones," Journal of Medicinal Chemistry, vol. 49, no. 24, pp. 7063-7075, 2006.

[47] S. Hourai, T. Fujishima, A. Kittaka et al., "Probing a water channel near the A-ring of receptor-bound $1 \alpha, 25$ dihydroxyvitamin D3 with selected $2 \alpha$-substituted analogues," Journal of Medicinal Chemistry, vol. 49, no. 17, pp. 5199-5205, 2006.

[48] A. Yoshida, K. Ono, Y. Suhara, N. Saito, H. Takayama, and A. Kittaka, "Efficient and convergent coupling route for the short-step synthesis of enantiopure $2 \alpha$ - and $2 \beta$-alkylated $1 \alpha, 25$-dihydroxy-19-norvitamin D3 analogues," Synlett, no. 8, pp. 1175-1179, 2003.

[49] M. A. Arai and A. Kittaka, "Novel 2-alkyl-1 $\alpha, 25$-dihydroxy19-norvitamin D3: efficient synthesis with Julia olefination, evaluation of biological activity and development of new analyzing system for co-activator recruitment," Anticancer Research, vol. 26, no. 4, pp. 2621-2631, 2006.

[50] M. A. Arai, K. I. Takeyama, S. Ito, S. Kato, T. C. Chen, and A. Kittaka, "High-throughput system for analyzing ligandinduced cofactor recruitment by vitamin D receptor," Bioconjugate Chemistry, vol. 18, no. 3, pp. 614-620, 2007.

[51] T. C. Chen, G. G. Schwartz, K. L. Burnstein, B. L. Lokeshwar, and M. F. Holick, "The in vitro evaluation of 25hydroxyvitamin $\mathrm{D}_{3}$ and 19-nor- $1 \alpha, 25$ - dihydroxyvitamin $\mathrm{D} 2$ as therapeutic agents for prostate cancer," Clinical Cancer Research, vol. 6, no. 3, pp. 901-908, 2000.

[52] T. C. Chen, M. F. Holick, B. L. Lokeshwar, K. L. Burnstein, and G. G. Schwartz, "Evaluation of vitamin D analogs as therapeutic agents for prostate cancer. Recent results in cancer research," in Vitamin D Analogs in Cancer Prevention and Therapy, J. Reichrath, M. Friedrich, and W. Tilgen, Eds., vol. 164, pp. 273-288, Springer, Berlin, Germany, 2003.

[53] T. C. Chen, K. S. Persons, S. Zheng et al., "Evaluation of C-2-substituted 19-nor-1 $\alpha, 25$-dihydroxyvitamin D3 analogs as therapeutic agents for prostate cancer," Journal of Steroid Biochemistry and Molecular Biology, vol. 103, no. 3-5, pp. 717$720,2007$.

[54] J. N. Flanagan, S. Zheng, K. C. Chiang et al., "Evaluation of 19-nor- $2 \alpha$ (3-hydroxypropyl)-1 $\alpha, 25$-dihydroxyvitamin $\mathrm{D}_{3}$ as a therapeutic agent for androgen-dependent prostate cancer," Anticancer Research, vol. 29, no. 9, pp. 3547-3553, 2009.

[55] Y. Ohyama, K. Ozono, M. Uchida et al., "Identification of a vitamin D-responsive element in the 5 -flanking region of the rat 25-hydroxyvitamin $\mathrm{D}_{3}$ 24-hydroxylase gene," Journal of Biological Chemistry, vol. 269, no. 14, pp. 10545-10550, 1994. 
[56] J. N. Flanagan, M. V. Young, K. S. Persons et al., "Vitamin D metabolism in human prostate cells: implications for prostate cancer chemoprevention by vitamin D," Anticancer Research, vol. 26, no. 4, pp. 2567-2572, 2006.

[57] I. Schuster, "Cytochromes P450 are essential players in the vitamin D signaling system," Biochimica et Biophysica Acta, vol. 1814, no. 1, pp. 186-199, 2011.

[58] D. Abe, T. Sakaki, T. Kusudo et al., "Metabolism of $2 \alpha$-propoxy-1 $\alpha, 25$-dihydroxyvitamin D3 and $2 \alpha$-(3-hydroxypropoxy)-1 $\alpha, 25$-dihydroxyvitamin $\mathrm{D}_{3}$ by human CYP27A1 and CYP24A1," Drug Metabolism and Disposition, vol. 33, no. 6, pp. 778-784, 2005.

[59] E. J. Bernhard, S. B. Gruber, and R. J. Muschel, "Direct evidence linking expression of matrix metalloproteinase 9 (92$\mathrm{kDa}$ gelatinase/collagenase) to the metastatic phenotype in transformed rat embryo cells," Proceedings of the National Academy of Sciences of the United States of America, vol. 91, no. 10, pp. 4293-4297, 1994.

[60] B. Y. Bao, S. D. Yeh, and Y. F. Lee, " $1 \alpha, 25$-dihydroxyvitamin D3 inhibits prostate cancer cell invasion via modulation of selective proteases," Carcinogenesis, vol. 27, no. 1, pp. 32-42, 2006.

[61] P. Polly, M. Herdick, U. Moehren, A. Baniahmad, T. Heinzel, and C. Carlberg, "VDR-Alien: a novel, DNA-selective vitamin D3 receptorcorepressor partnership," FASEB Journal, vol. 14, no. 10, pp. 1455-1463, 2000. 


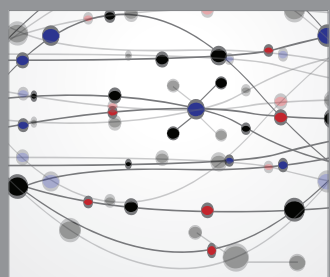

The Scientific World Journal
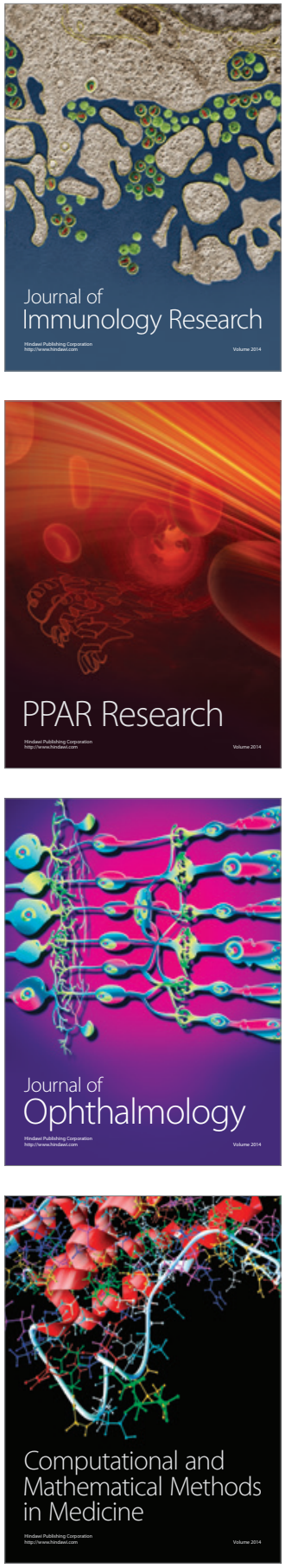

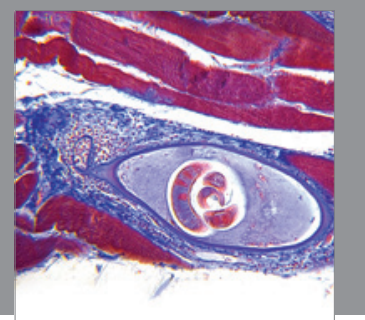

Gastroenterology

Research and Practice
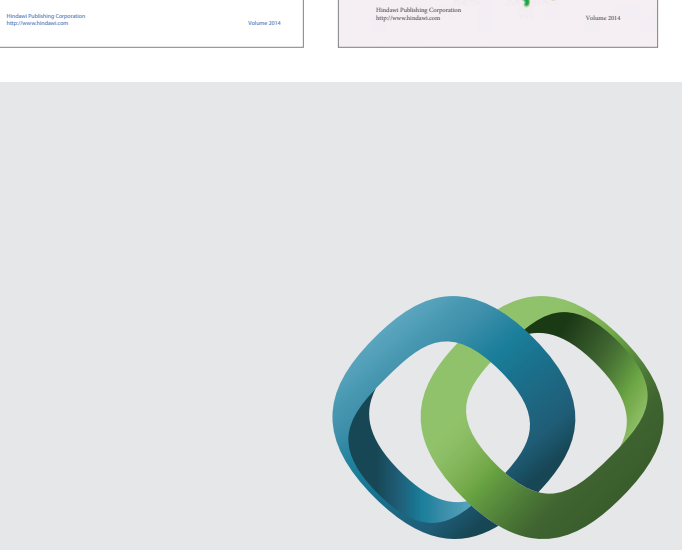

\section{Hindawi}

Submit your manuscripts at

http://www.hindawi.com
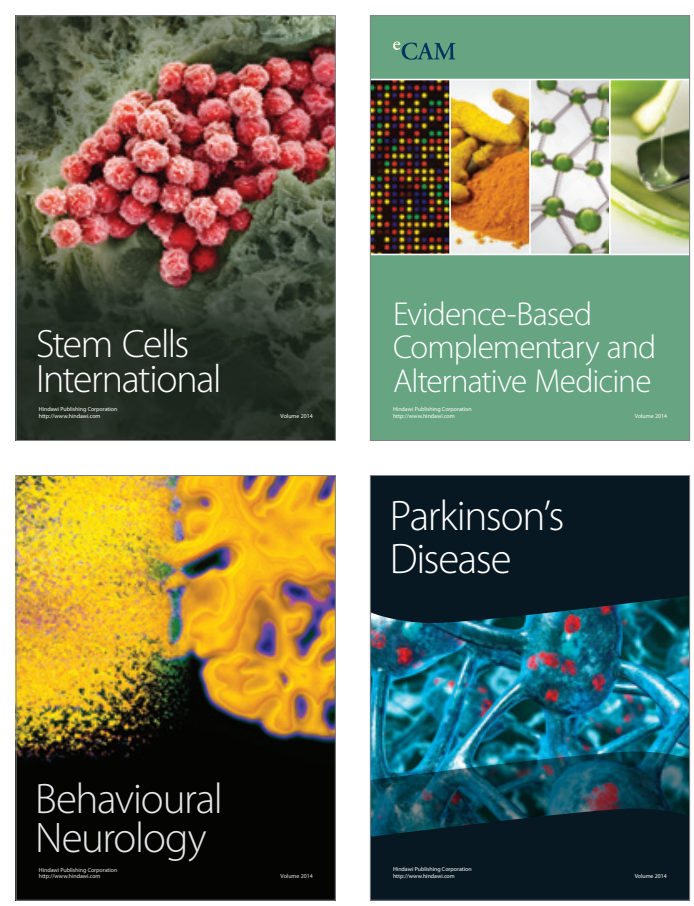

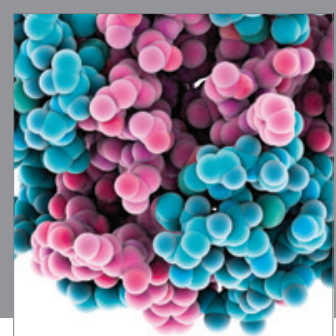

Journal of
Diabetes Research

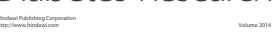

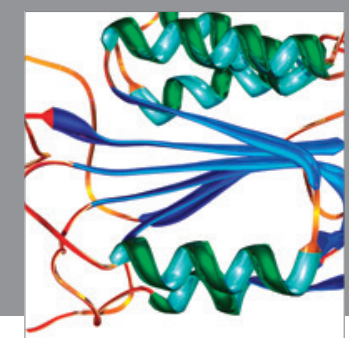

Disease Markers
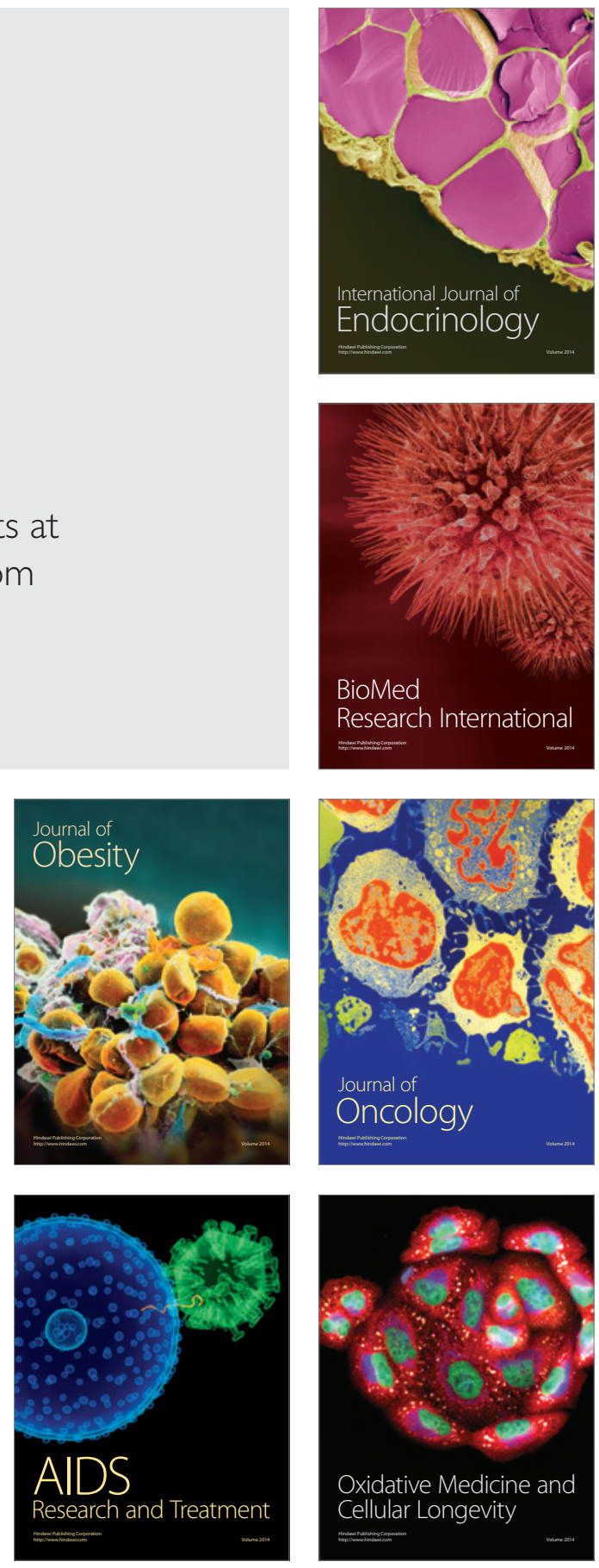